Anglophobia in Fascist Italy

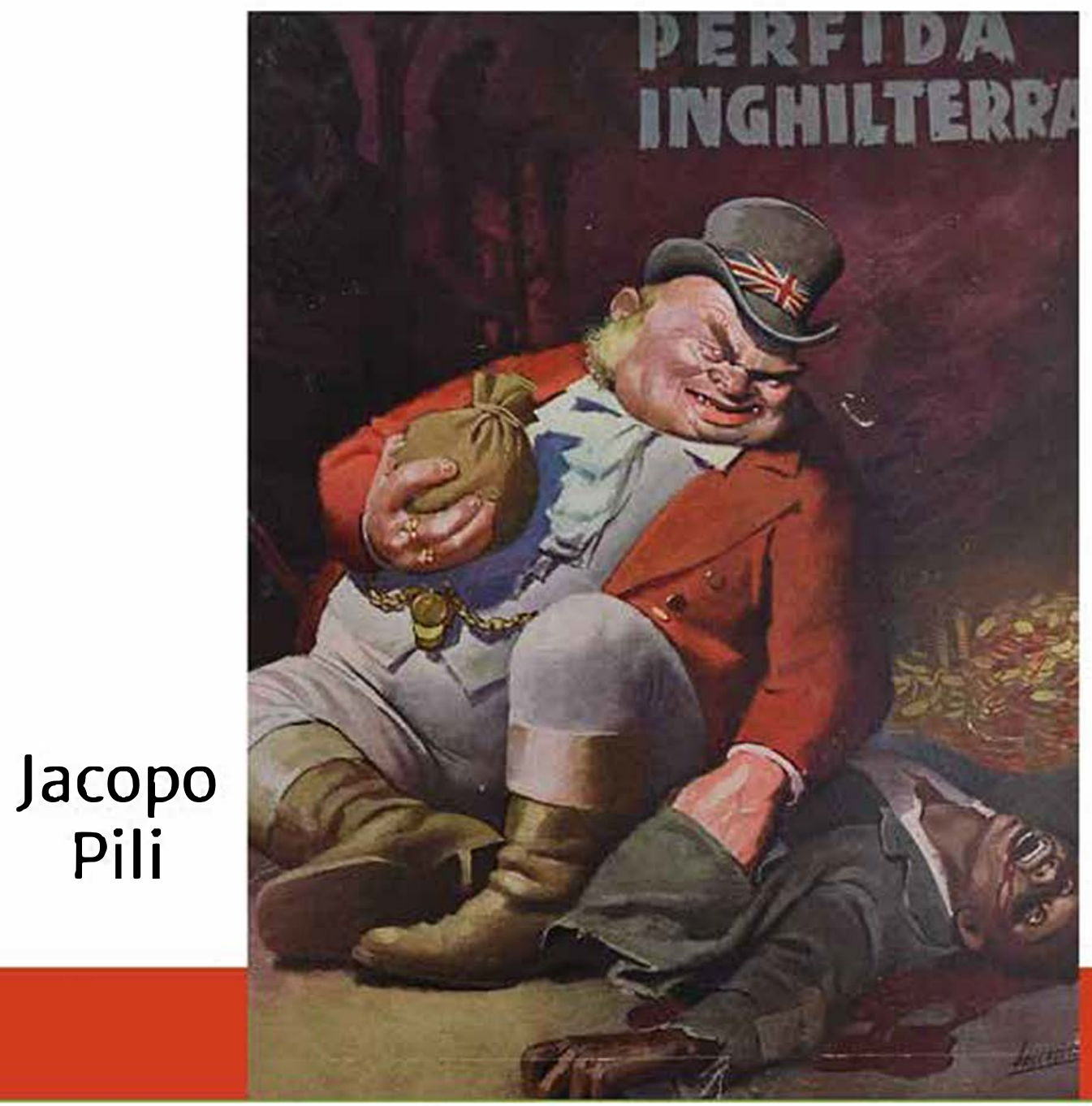

MANCHESIER 
ANGLOPHOBIA IN FASCIST ITALY 
Jacopo Pili - 9781526159663 Downloaded from manchesterhive.com at 04/26/2023 01:05:47PM via free access 


\section{Anglophobia in Fascist Italy}

20

Jacopo Pili 


\section{Copyright (C) Jacopo Pili 202I}

The right of Jacopo Pili to be identified as the author of this work has been asserted by him in accordance with the Copyright, Designs and Patents Act 1988.

This electronic version has been made freely available under a Creative Commons (CC-BY-NC-ND) licence, which permits non-commercial use, distribution and reproduction provided the author(s) and Manchester University Press are fully cited and no modifications or adaptations are made. Details of the licence can be viewed at creativecommons.org/licenses/by-nc-nd/4.0/

Published by Manchester University Press

Oxford Road, Manchester MI3 9 PL www.manchesteruniversitypress.co.uk

\section{British Library Cataloguing-in-Publication Data}

A catalogue record for this book is available from the British Library

ISBN 978 I 526 I 59656 hardback

ISBN 978 I 526159649 open access ePub ISBN 978 I 526159663 open access web PDF

Digital editions first published 2022

Print edition first published 2022

The publisher has no responsibility for the persistence or accuracy of URLs for any external or third-party internet websites referred to in this book, and does not guarantee that any content on such websites is, or will remain, accurate or appropriate. 


\section{S $\mid \mathrm{H}$ The Sustainable History Monograph Pilot \\ MI P Opening Up the Past, Publishing for the Future}

This book is published as part of the Sustainable History Monograph Pilot. With the generous support of the Andrew W. Mellon Foundation, the Pilot uses cutting-edge publishing technology to produce open access digital editions of high-quality, peer-reviewed monographs from leading university presses. Free digital editions can be downloaded from: Books at JSTOR, EBSCO, Hathi Trust, Internet Archive, OAPEN, Project MUSE, and many other open repositories.

While the digital edition is free to download, read, and share, the book is under copyright and covered by the following Creative Commons License: BY-NC-ND 4.0. Please consult www.creativecommons.org if you have questions about your rights to reuse the material in this book.

When you cite the book, please include the following URL for its Digital Object Identifier (DOI): https://doi.org/10.7765/9781526159663

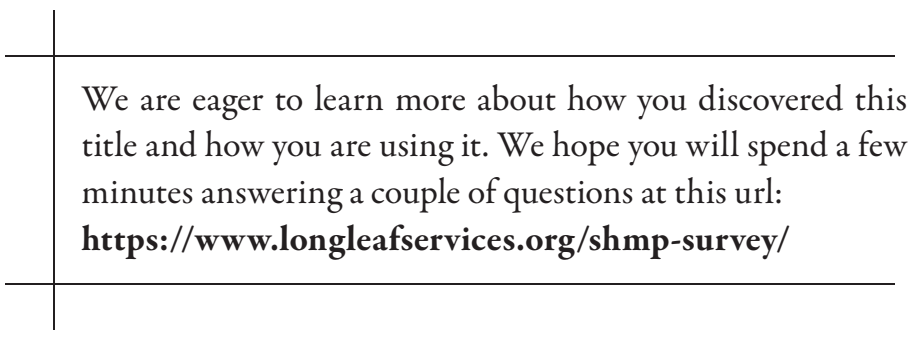

More information about the Sustainable History Monograph Pilot can be found at https://www.longleafservices.org. 
Jacopo Pili - 9781526159663 Downloaded from manchesterhive.com at 04/26/2023 01:05:47PM via free access 